\title{
PEMANFAATAN UBI KAYU MENJADI TEPUNG MOCAF UNTUK DIVERSIFIKASI DAN PENINGKATAN PENDAPATAN USAHA MIKRO KECIL MENENGAH DI DESA SERASAH KABUPATEN BATANG HARI
}

\author{
Indriyani, Ika Gusriani dan Irma Rahmayani
}

Staf Pengajar Fakultas Teknologi Pertanian Universitas Jambi

email: indriyani@unja.ac.id; gusrieone@yahoo.com; pecintaharmoni@gmail.com

\begin{abstract}
ABSTRAK
Kegiatan Pengabdian Kepada Masyarakat ini bertujuan memberikan pengetahuan dan informasi pada masyarakat Desa Serasah Kecamatan Pemayung Kabupaten Batang Hari khususnya Usaha Mikro Kecil Menengah Melati dan Seroja tentang pemanfaatan ubi kayu menjadi tepung ubi kayu yang dimodifikasi (Modified Cassava Flour/Mocaf) sebagai bahan diversifikasi tepung terigu pada pembuatan aneka kue khususnya brownies, Penabdian Kepada Masyarakat ini dilakukan dengan cara penyuluhan cara membuat Mocaf dan memperlihatkan produk Mocaf hasil pengolahan dari Ubi Kayu, presentasi dan praktek langsung cara pemanfaatan Mocaf terhadap salah satu produk Kue, selanjutnya mempresentasikan dan memperlihatkan pengemasan yang baik dan benar sesuai standar pengemasan. Kegiatan Pengabdian kepada Masyarakat di dilakukan di Balai Desa Serasah Kabupaten Batang Hari. Kesediaan dan partisipasi aktif masyarakat selama proses berlangsung sangat tinggi. Hal ini diperlihatkan dengan antusiasme masyarakat yang ingin diberi kesempatan untuk melakukan proses pemanfaatan Mocaf menjadi produk olahan kue yang lain selain Brownies. Pada bagian akhir, kedua mitra mendapat Bantuan berupa Alat Penunjang Produksi diantaranya Oven Listrik, Mixer dan Kompor Gas. Kesimpulan kegiatan Pengabdian pada Masyarakat ini sangat diapresiasi oleh kedua Mitra untuk kedepannya akan memanfaatkan Tepung Mocaf sebagai pengganti Tepung Terigu dan sebagai salah satu solusi mengatasi ketergantungan terigu pada pelaku usaha Kue dan Makanan Tradisional.
\end{abstract}

Kata Kunci : Ubi Kayu, Tepung Mocaf, Brownies, Serasah, Seroja, Melati

\section{PENDAHULUAN}

Desa Serasah merupakan salah satu desa yang berada di Kecamatan Pemayung Kabupaten Batang Hari, Jambi. Berdasarkan data yang tercatat dalam arsip desa, pada tahun 2016 jumlah penduduk Desa Serasah berjumlah 1.422 jiwa yang tersebar di 5 RT (Riduan, 2017). Secara geografis, Desa Serasah terletak di bagian timur Kabupaten Batang Hari dengan luas wilayah 3200 Ha. Wilayah bagian utara berbatasan dengan Desa Ture, Bagian Selaan berbatasan dengan Desa Awin, bagian timur berbatasan dengan Desa Pulau Betung dan Kabupaten Muaro Jambi sedangkan bagian Barat berbatasan dengan kelurahan Jembatan Mas. Adapun jarak tempuh Desa Serasah dengan Muara Bulian sebagai Ibu Kota Kabupaten $31 \mathrm{Km}$ dan dengan Ibu Kota Provinsi Jambi (Kota Jambi) adalah 33 Km. (Sabirin, 2014). Di Kabupaten Batang Hari sendiri, jumlah luas panen $66 \mathrm{Ha}$ dan produksi mencapai 1.004 Ton pada tahun 2014 (BPS, 2017).

Ada dua UMKM yang ada di Desa serasah yaitu UMKM Melati yang ada di Dusun I dan UMKM Seroja yang ada di Dusun II. Kedua UMKM ini sama-sama bergerak di bidang 
pembuatan aneka Kue dan makanan jajanan tradisional. Sasaran penjualan dari hasil produksi biasanya untuk acara-acara kenduri, seminar dan presentasi di kantor-kantor pemerintah, acara kumpul desa, makanan jajanan untuk Sekolah-sekolah di Desa Serasah dan lain sebagainya.

Tingginya minat dan antusias warga khusunya pelaku UMKM untuk mengembangkan produksi dan perluasan pemasaran dapat dilihat sewaktu respon mereka pada kunjungan survei pertama, dengan mengetahui pemanfaatan Ubi kayu selain digunakan untuk pembuatan gaplek, keripik, ubi goreng/rebus dan tepung tapioka juga dapat dimanfaatkan dalam bentuk tepung Mocaf yang berpotensi sebagai bahan penambah atau pengganti terigu, hal ini dikarenakan hampir setiap pekarangan rumah-rumah warga di Desa Serasah memiliki tanaman Ubi kayu, sehingga memacu keingintahuan dan respon positif dari seluruh warga. Dengan kondisi tersebut, untuk itulah dilakukan upaya sosialisasi, penyuluhan, pembimbingan dan demontrasi pemanfaatan Tepung Ubi Kayu yang dimodifikasi yang diaplikasikan ke produk Brownies, ditambah sosialisasi pengemasan yang baik dan menarik untuk memperpanjang umur simpan.

Luaran kegiatan pengabdian kepada masyarakat ini adalah 1). Artikel ilmiah tentang pemanfaatan ubi kayu menjadi tepung mocaf (Modified Cassava Flour) pada pembuatan brownies dalam rangka diversifikasi pangan, peningkatan nilai ekonomis dan pendapatan Usaha Mikro Kecil dan Menengah (UMKM). 2). Modul yang berisi informasi tentang keunggulan tepung mocaf, teknik pembuatan tepung mocaf serta pemanfaatannya menjadi brownies. 3) Pengemasan yang baik pada tepung mocaf dan brownies yang dihasilkan sehingga memperpanjang umur simpan dan menarik konsumen.

\section{METODE PELAKSANAAN}

Tepung Mocaf (Modified Cassava Flour) dari Ubi Kayu yang merupakan hasil pertanian lokal sehingga mengurangi penggunaan Tepung terigu/Gandum dan diharapkan mampu menurunkan biaya produksi. Ditambahkan oleh Subagio (2008) yang menyatakan Mocaf atau tepung Ubi Kayu yang dimodifikasi adalah produk tepung yang diproses dengan menggunakan prinsip modifikasi sel ubi kayu secara fermentasi. Proses fermentasi menyebabkan perubahan karakteristik yang dihasilkan berupa naiknya viskositas, kemampuan gelasi, gaya rehidrasi dan kemampuan melarut yang menyebabkan tepung ubi kayu terfermentasi memiliki karakteristik dan kualitas hamper sama menyerupai tepung terigu (Salim, 2007).

Pengetahuan tentang pemanfaatan tepung mocaf ke proses pembuatan kue-kue dan cake yang selama ini belum dilakukan dan disosialisasikan secara maksimal. Selain penggunaan tepung mocaf, dilakukan sosialisasi pembuatan brownies dari tepung mocaf dengan tujuan penganekaragaman kue-kue tradisional yang diproduksi. Selain pengetahuan pelaku UMKM mengenai pengembangan dan diversifikasi tepung mocaf yang sangat minim, juga pengetahuan mengenai teknik pengemasan yang menarik agar produk yang dihasilkan memiliki nilai jual masih sangat terbatas. Oleh karena itu, solusi yang ditawarkan adalah melakukan sosialisasi dan pelatihan kepada anggota UMKM Melati dan UMKM Seroja. Materi pelatihan berupa penyuluhan (ceramah) dan praktek (demonstrasi) meliput: 

a. Sosialisasi tentang tepung ubi kayu modifikasi (Mocaf)
b. Sosialisasi tentang proses pemanfaatan tepung mocaf ke berbagai produk kue
c. Pengolahan brownies dari tepung mocaf
d. Teknik pengemasan tepung mocaf dan brownies yang baik dan menarik

Kegiatan-kegiatan yang dilakukan :

1. Pelatihan pembuatan tepung mocaf

2. Pelatihan pemanfaatan tepung mocaf pada pembuatan brownies

3. Pelatihan teknik pengemasan tepung mocaf dan brownies yang baik dan menarik.

4. Monitoring dan evaluasi dari berbagai tahap kegiatan yang dilakukan.

\section{HASIL DAN PEMBAHASAN}

\section{Hasil yang Dicapai}

Pengabdian kepada masyarakat ini telah berhasil membuat tepung mocaf (Modified Cassava Flour) dari ubi kayu dengan perlakuan fermentasi perendaman di dalam air selama 4 hari. Tepung mocaf yang dihasilkan berwarna putih bersih, tidak ada bau langu ubi kayu, kehalusan yang bagus untuk digunakan sebagai pengganti tepung terigu, dan juga aroma yang sesuai untuk pembuatan produk-produk kue dan cake.

Penggunaan tepung mocaf pada produk kue dan cake terutama produk brownies menghasilkan brownies yang lembut, dengan aroma serta tekstur yang cocok untuk brownies dan dapat diaplikasikan pada proses pemanggangan ataupun pengukusan, tanpa mengurangi rasa dan aroma brownies yang dihasilkan. Berdasarkan percobaan yang telah dilakukan, brownies dengan pemanfaatan tepung mocaf $100 \%$ lebih enak, kenyal dan beraroma baik jika dibandingkan dengan penggunaan tepung mocaf : tepung terigu dengan perbandingan $1: 1$ atau pun tepung mocaf : tepung terigu dengan perbandingan $3: 7$. Penggunaan tepung mocaf bukan sekedar menambahkan atau sebagai pelengkap, tapi berperan menggantikan 100\% keberadaan tepung terigu pada produk brownies, sehingga brownies yang dihasilkan tidak menggunakan tepung terigu sama sekali.

Pembuatan contoh kemasan dan design produk tepung mocaf dan brownies yang baik dan menarik dibuat dengan memperhatikan hal-hal penting yang harus ditampilkan dalam kemasan produk. Bahan kemasan seperti karton, plastik, kaleng dan lain sebagainya menjadi salah satu hal penting yang perlu dipertimbangkan dalam memilih kemasan yang baik dan menarik. Selain bahan kemasan, yang juga penting dalam membuat kemasan dan design produk adalah penyampaian informsi yang lengkap tentang produk brownies yang dihasilkan seperti komposisi, waktu kadaluarsa, halal, serta izin peredaran produk.

Adapun hasil yang dicapai dari Program Pengabdian Kepada Masyarakat ini adalah :

1. Bertambahnya pemahaman masyarakat mengenai pemanfaatan ubi kayu menjadi tepung mocaf yang memiliki banyak keunggulan dibandingkan dengan tepung terigu.

2. Meningkatnya keterampilan masyarakat dalam mengolah ubi kayu menjadi tepung mocaf serta pemanfaatannya menjadi produk olahan pangan yaitu brownies yang bernilai jual tinggi. 
3. Bertambahnya pengetahuan masyarakat mengenai teknik pengemasan dan design produk yang baik dan menarik.

\section{Pembahasan}

Kegiatan pengabdian kepada masyarakat ini diawali dengan koordinasi dengan Ibu Ketua PKK Desa Serasah, mengenai kesediaan sebagai penghubung antara Tim Pelaksana Pengabdian dengan mitra UMKM yang ada di Desa Serasah. Mitra yang ada di Desa Serasah berupa UMKM yang bergerak dibidang kuliner yaitu UMKM Seroja dan Melati. Selanjutnya dibuat modul sederhana mengenai keunggulan mocaf sebagai bahan pengganti tepung terigu, prinsip teknologi pengolahan ubi kayu menjadi tepung mocaf ((Modified Cassava Flour) dan brownies berupa prosedur dan skema alir, serta informasi tentang kemasan dan design produk yang baik dan menarik.

Pelaksanaan kegiatan pengabdian dilakukan dalam bentuk penyuluhan (ceramah) untuk meningkatkan pemahaman dan keterampilan masyarakat dalam mengolah ubi kayu menjadi tepung mocaf dan brownies yang memiliki nilai gizi dan nilai jual yang tinggi, selain itu juga memberikan informasi mengenai keunggulan tepung mocaf dibandingkan tepung terigu yang selama ini digunakan sebagai bahan dasar dalam berbagai macam produk olahan pangan. Demonstrasi atau praktek secara langsung juga dilakukan dalam kegiatan ini yaitu bagaimana membuat brownies dengan bahan dasar tepung mocaf serta bagaimna teknik pengemasannya.

Luaran yang dicapai dari pelaksanaan Program Pengabdian Kepada Masyarakat adalah sebagai berikut :

1. Artikel ilmiah yang akan disubmit pada Jurnal LPPM UNJA.

2. Modul mengenai keunggulan mocaf sebagai bahan pengganti tepung terigu, prinsip teknologi pengolahan ubi kayu menjadi tepung mocaf ((Modified Cassava Flour) dan brownies serta informasi tentang kemasan dan design produk yang baik dan menarik.

3. Produk berupa tepung mocaf, brownies dan contoh design kemasan.

\section{rencana tahapan berikutnya}

Pelaksanaan pengabdian kepada masyarakat yang dilakukan telah berhasil membuat tepung mocaf dari ubi kayu dengan menggunakan teknik fermentasi sederhana yaitu perendaman dengan air selama 4 hari dengan kondisi anaerob/tertutup tanpa adanya oksigen yang keluar-masuk selama perendaman, dari perendaman ini diperoleh tepung mocaf yang cocok digunakan sebagai pengganti tepung terigu pada beberapa produk kue dan cake terutama produk brownies.

Tingginya antusiasme masyarakat dalam pengolahan ubi kayu menjadi tepung mocaf, mendorong Tim Pelaksana Pengabdian untuk merencanakan tahapan pengabdian berikutnya yang berfokus pada pengemasan dan penyimpanan tepung mocaf disertai pengembangan jangkauan pemasaran tepung mocaf yang diproduksi secara luas, kalau memungkinkan pemasaran dilakukan sampai diluar dari Desa Serasah, sehingga dapat dijadikan salah satu sumber produk olahan yang dapat meningkatkan pendapatan masyarakat terutama pelaku UMKM yang ada di Desa Serasah. 
Masih banyaknya produk olahan yang dapat dikembangkan dengan memanfaatkan tepung mocaf, sehingga perlu percobaan apakah tepung mocaf tersebut dapat diaplikasikan sebagai subtitusi atau diversifikasi pada suatu produk olahan baik itu kue ataupun cake, sehingga perlu pengembangan lebih lanjut untuk dapat menghasilkan suatu produk makanan jajanan, olahan kue dan cake yang murah, sehat, dan bergizi.

\section{KESIMPULAN DAN SARAN}

\section{Kesimpulan}

Kegiatan pengabdian kepada masyarakat ini menambah pengetahuan kelompok Usaha Mikro Kecil dan Menengah (UMKM) serta anggota ibu-ibu PKK di Desa Serasah Kecamatan Pemayung Batang Hari dengan memanfaatkan ubi kayu yang melimpah untuk dijadikan tepung mocaf (Modified Cassava Flour), sebagai pengganti penggunaan tepung terigu pada sejumlah cake dan kue-kue khususnya pembuatan brownies. Tingginya minat ibu-ibu PKK yang ikut program pengabdian ini dalam mengembangkan dan memanfaatkan ubi kayu yang ada untuk dijadikan tepung mocaf dan dijadikan bahan pengganti tepung terigu pada beberapa produk kue dan cake yang lain, sehingga mendorong Tim Pelaksana Pengabdian untuk mengembangkan sejumlah ide dan perbandingan antara penggunaan tepung mocaf dan tepung terigu yang sesuai untuk beberapa produk kue dan cake. Selanjutya mendorong Tim Pelaksana Pengabdian untuk memberikan saran terkait pengemasan yang baik pada produk tepung yang dihasilkan sehingga bisa awet dan dapat disimpan dalam waktu yang lama.

\section{Saran}

Berdasarkan hasil kegiatan yang telah dilakukan, disarankan untuk melanjutkan kegiatan pengabdian ini berupa pendampingan dalam pembuatan usaha pengolahan tepung mocaf dan diaplikasikan ke beberapa produk kue dan cake lainnya berdasarkan kelayakan ekonomis usahanya. Selain itu, perlu dilakukan kegiatan tentang teknik pemasaran yang baik sehingga produk tepung mocaf yang diproduksi dapat dipasarkan secara luas.

\section{DAFTAR PUSTAKA}

BPS. 2017. Produksi Ubi Kayu Menurut Provinsi-Kabupaten (ton) tahun 2014. Bps.go.id (Diakses pada 08 Maret 2017).

Riduan. 2017. Rencana Pembangunan Jangka Menengah Desa (RJM-DES) Tahun 2014-2017. Peraturan Daerah Kabupaten Muaro Jambi Nomor 29 Tahun 2009. Serasah.

Sabirin, Amat. 2014. Rencana Pembangunan Jangka Menengah Desa (RJM-DES) Tahun 2009-2014. Peraturan Daerah Kabupaten Muaro Jambi Nomor 29 Tahun 2009. Serasah.

Salim, E. 2007. Mengolah Singkong menjadi Tepung Mocaf (Bisnis Produk Alternatif Pengganti Terigu). Lily Publisher. Yogyakarta

Subagio, A. 2008. Modified Cassava Flour (Mocal): sebuah Masa Depan Ketahanan Pangan Nasional Berbasis Potensi Lokal. Universitas Jember. Jember 